UDC $340.12,349.2$

Kovalchuk Alla,

Doctor of Juridical Sciences, Associate

Professor, Professor of the Department

of Private and Public Law at the

KNUTD, Kyiv, Ukraine

ORCID ID 0000-0003-4807-2436

\title{
Koval Olha,
}

Candidate of Juridical Sciences, Associate Professor of the Department of Private and Public Law at the KNUTD, Kyiv, Ukraine

ORCID ID 0000-0003-1509-7258

\section{GENDER BALANCE IN THE LEGISLATION ON SECURITY MATTERS (THE EXAMPLE OF ANTY-MINE ACTIVITIES IN UKRAINE)}

The research material presented in this publication had been reflected in the adopted Law of Ukraine «On Mine Action in Ukraine» approved on December 6, 2018, but some positions on ensuring the principle of gender equality need some clarification. The aim of the article is to develop possible ways of introducing the gender balance aspect into the modern life of Ukrainians. The need to align current European standards for mine action in Ukraine, including gender equality, is noted. Overcoming the barrier between European society and Ukrainian society should begin with traverse the gender stereotypes. The new philosophical approach to building a modern Ukrainian society and securing a gender balance is sought, especially in the pursuit of extremely dangerous activities. On the one hand, women are given equal rights with men, on the other hand, there are artificial obstacles for women in their desire to perform work on an equal basis with men. 
As a result of the research, proposals to the current legislation of Ukraine on mine action are formulated and clarifications of understanding of gender equality in the specified activity are offered. The necessity to introduce a number of legal and organizational changes in the modern concept of gender equality in Ukraine has been proved. It is necessary to take into account the provisions of the Council of Europe's Gender Equality Strategy for 2018 - 2023 in the process of forming the legislative base, build on the strategic course of Ukraine's development - integration into the European Union.

Keywords: gender equality, gender stereotypes, participation of women in extremely dangerous activities, danger, mine action, military clearance, humanitarian clearance.

\section{REFERENCES}

1. Ivanna Klympush-Tsyntsadze (2018) prezentuvala rezultaty pershoho natsionalnoho opytuvannia shchodo rivnosti cholovikiv ta zhinok. "Ivanna KlimpushTsintsadze presented the results of the first national poll on equality between men and women". URL: https://www.kmu.gov.ua/ua/news/ivanna-klimpush-cincadzeprezentuvala-rezultati-pershogo-nacionalnogo-opituvannya-shchodo-rivnosticholovikiv-ta-zhinok (date of application: 14.10.2019) [in Ukrainian].

2. Pro zatverdzhennia Derzhavnoi tsilovoi prohramy protyminnoi diialnosti Ministerstva z pytan nadzvychainykh sytuatsii ta u spravakh zakhystu naselennia vid naslidkiv Chornobylskoi katastrofy na 2009 - 2014. "On approval of the State Targeted Mine Action Program of the Ministry for Emergency Situations and for the Protection of the Population from the Consequences of the Chornobyl Catastrophe for 20092014". Resolution of the Cabinet of Ministers of Ukraine, 18 february 2009 year No.

131 URL: https://zakon.rada.gov.ua/laws/show/131-2009-\%D0\%BF (date of application: 14.10.2019) [in Ukrainian].

3. Konstytutsiia Ukrainy, pryiniata na piatii sesii Verkhovnoi Rady Ukrainy 28 lypnia 1996. "Constitution of Ukraine, primacy at the five sessions of the Verkhovna Rada of Ukraine on June 28, 1996”. K.: 1996. 64 p. [in Ukrainian].

4. Kodeks zakoniv pro pratsiu Ukrainy. "Labor Code of Ukraine No. 322VIII dated 10.12.71": IVR, 1971, No. 50, Art. 375. 
URL:https://zakon.rada.gov.ua/laws/show/322-08 (date of application: 14.10.2019) [in Ukrainian].

5. Yak $\mathrm{v}$ Ukraini dolaiut dyskryminatsiiu zhinok $\mathrm{v}$ armii. "How to Discriminate Women in the Army in Ukraine" (2018). URL: https://www.bbc.com/ukrainian/features-44722205 (date of application: 14.10.2019) [in Ukrainian].

6. Mizhnarodni standarty protyminnoi diialnosti. Kerivnytstvo po stvorenniu prohramy z pytan protyminnoi diialnosti. "International standards of mine action". A guide to creating a mine action program. URL: http://www.mil.gov.ua/content/standarts/IMAS\%2002.10_ua.pdf (date of application: 14.10.2019) [in Ukrainian].

7. Zhinky v armii - tse normalno. "Women in the Army - this is normal" (2018). URL: https://www.pravda.com.ua/columns/2018/09/11/7191695/ (date of application: 14.10.2019) [in Ukrainian].

8. Stratehiia hendernoi rivnosti Rady Yevropy na 2018-2023 roky. "The Council of Europe's Gender Equality Strategy for 2018-2023”. URL: https://rm.coe.int/prems-041318-gbr-gender-equality-strategy-2023-ukrnew2/16808b35a4 (date of application: 14.10.2019) [in Ukrainian].

9. Dmytriieva M.M. Linhvistychnyi eksperyment yak instrument dlia vymiriuvannia hendernoi chutlyvosti. "Linguistic experimentation as a tool for measuring gender sensitivity". URL: www.linguistics.kiev.ua / seminar /2003/12/18/ sem 01_02_7. html 4. (date of application: 14.10.2019) [in Ukrainian].

10. Dmitriieva M.M. Henderna terminolohiia: natsionalne vs. internatsionalne. "Gender terminology: national vs. international". URL: http://www.linguistics.kiev.ua /seminar/2005 /03/07/ seminar_3_genderna_t_35.html (date of application: 14.10.2019) [in Ukrainian].

11. Ukraina pryiniala mizhnarodni standarty $\mathrm{z}$ protyminnoi diialnosti. "Ukraine has adopted international standards for mine action".URL: http://www.me.gov.ua/News/Detail?lang=uk-UA\&id=10ec4218-5549-4759-9ceded23e8470126\&title=UkrainaPriinialaMizhnarodniStandartiZProtiminnoiDiialnosti (date of application: 14.10.2019) [in Ukrainian]. 
12. Pro uporiadkuvannia robit $\mathrm{z}$ vyiavlennia, zneshkodzhennia ta znyshchennia vybukhonebezpechnykh predmetiv. "On the ordering of works on the detection, disposal and destruction of explosive objects". Decree of the Cabinet of Ministers of Ukraine of December 11, 1999. No. 2294. URL: http://uainfo.biz/legal/basetp/ua-zmpxbu.htm (date of application: 14.10.2019) [in Ukrainian]. 